\title{
Systematic and molecular biological study of Sambucus L. (Caprifoliaceae) in Iran
}

\author{
Elham Amini ${ }^{1}$, Fatemeh Nasrollahi ${ }^{2}$, Ali Sattarian ${ }^{1 *}$, Mohsen Isazadeh-Araei ${ }^{1}$, Meisam $^{2}$ \\ $\mathrm{Habibi}^{1}$
}

${ }^{1}$ Department of Biology, Faculty of Sciences, Gonbad Kavous University, Gonbad, Iran. ${ }^{2}$ Department of Biology, Faculty of Sciences, University of Qom, Qom, Iran.

*Corresponding author: Sattarian.ali@gmail.com

Amini E., Nasrollahi F., Sattarian A., Isazadeh-Araei M. \& Habibi M. (2019): Systematic and molecular biological study of Sambucus L. (Caprifoliaceae) in Iran. - Thaiszia - J. Bot. 29 (2): 133-150

Abstract: Sambucus is a medicinal plant with approximately 25 accepted taxa in the world from which two are present in Iran, S. nigra and S. ebulus. In order to evaluate the affinities and relationships in Sambucus and resurrect subspecies or verities in these two species, the micro-morphological, anatomical and molecular properties of Sambucus species of Iran have been studied. Pollen and seed surfaces of two species were examined with scanning electron microscope. In micro-morphological studies, the pollen shape is prolate-spheroidal in S. nigra but subprolate in S. ebulus. The exine sculpture is microperforate in S. nigra and is reticulate-microechinate in S. ebulus. The surface of the seed in S. nigra is smooth, not elongated and no clear organizational pattern is discernable and the anticlinal walls are shallowly undulate. In S. ebulus, the seeds have a microperforate surface and the anticlinal walls are observed deeply undulate. Petiole anatomical studies show that vascular bundles and existence of druse crystals are diagnostic characters in studied species. Using nuclear (nrDNA ITS) marker, we reconstructed phylogenetic relationships within two species of Sambucus. The ITS dataset was analyzed by phylogenetic methods including Bayesian inference, maximum likelihood and maximum parsimony. In phylogenetic analyses, all members of this genus form a well-supported clade (PP $=1, \mathrm{ML} / \mathrm{BS}=100 / 100)$. The Sambucus clade is composed of two clades. Clade I includes the populations of S. nigra and the clade II comprises the rest of the species of Sambucus (S. ebulus). NeighborNet diagram demonstrated separation of the studied populations. In general, molecular studies supported micro-morphological findings. Pollen, seed-coat characters and molecular phylogeny support the separation of S. nigra and S. ebulus

Keywords: Iran, micro-morphological, molecular, nrDNA ITS, pollen, Sambucus, seed. 


\section{Introduction}

Sambucus L. (Caprifoliaceae) is a small genus of approximately 25 species of deciduous shrubs, small trees and a few perennial herbs (Mabberley 2008). It is mainly distributed in temperate and subtropical regions of the Europe, Asia, North Africa, and naturalized in the United States. Sambucus consists of two species in Iran namely, S. ebulus L. and S. nigra L. The species of Sambucus are distributed in north, northwest and northeast of Iran (Jamzad 1993). These plants are deciduous shrub or more rarely a small tree to $10 \mathrm{~m}$, often with straight, vigorous erect shoots from the base. The leaves are pinnate to ovate-lanceolate or ovate-elliptic. Cream-white flowers are pentamerous and actinomorphic. The fruit is a drupe and containing 3-5 compressed seeds. Pollen grains are pale yellow, ellipsoidal and densely tuberculated (Judd et al. 2007). As a medicinal plant, the genus has been used for their diaphoretic, laxative and diuretic properties (Uncinimanganelli et al. 2005; Merica et al. 2006) and to treat various illnesses such as stomach ache, sinus congestion, constipation, diarrhea, sore throat, common cold and rheumatism (Novelli 2003; Uncinimanganelli et al. 2005).

Micro-morphological characters are of good diagnostic value to recognize many taxa, principally at the species level. Palynological studies for this genus are not so extensive (Accorsi et al. 1987; Hu \& He 1988; Chen et al. 1992; Du et al. 2007). Punt et al. (1976) divided the family Caprifoliaceae into 10 distinct pollen types, Lonicera alpigena-type, Lonicera caprifolium-type, Lonicera coerulea-type, Lonicera periclymenum-type, Lonicera xylosteumtype, Sambucus ebulus-type, Sambucus nigra-type, Viburnum lantana-type, Viburnum opulus-type and Viburnum tinus-type. Maciejewska (1997) studied 5 polish species (genera Sambucus and Viburnum L.), and results showed that all examined species have small to medium-sized grains, with prolate polar axis and reticulate ornamentation. Hu et al. (1996) studied the seed micromorphology of Sambucus in Jilin province preliminary and show that Sambucus endocarps provide highly reliable diagnostic characteristics at both of generic and specific levels. The anatomical structure of these species has not been studied yet. Petiole anatomical studies in Caprifoliaceae have provided diagnostic features in some taxa (Gundersen 1910; Petit 1887). Molecular data have been used in phylogenetic and species divergence studies (Sheidai et al. 2014, 2016). These data can also provide supportive and extra criteria for systematic classification of the species studied that have been only based on the morphological characters (Chen et al. 1992). The internal transcribed spacer (ITS) is the region of the 18S5.8S- 26S nuclear ribosomal cistron (Baldwin et al. 1995). Several phylogenetic studies of Dipsacales have appeared in recent years, based on molecular evidence (Judd et al. 1994; Backlund \& Donoghue 1996; Pyck et al. 1999; Pyck \& Smets 2000; Bell et al. 2001; Donoghue et al. 2001, 2003) and they clarified phylogenetic relationships within Adoxaceae and Caprifoliaceae.

Since there is no comprehensive systematic study on Sambucus species in Iran and Sambucus nigra is located in the Arasbaran region with very limited distribution, the researchers have encouraged to study the genus Sambucus in 
Iran. Moreover, due to different populations of Sambucus nigra and S. ebulus collected from different parts of Iran, we expect to resurrect subspecies or verities in these two species. Therefore, the objective of present study is to investigate the genus Sambucus in Iran and specifically (1) to find diagnostic micro-morphological characters, (2) to investigate molecular properties of Sambucus in Iran and (3) to evaluate the affinities and relationships of taxa.

\section{Material and Methods}

In the present study, 18 populations from two Sambucus species including three populations of $S$. nigra and 15 populations of $S$. ebulus were collected during spring and summer in 2016 from Iran (Tab. 1, Fig. 1) and preserved in the Gonbad Kavous University herbarium (GKUH). The Flora Iranica (Wendelbo 1965) was used for the identification.

\section{Morphological methods}

The palynological part of this study was made using Olympus Light Microscope (LM, VANOX AHBS3, Japan) and Scanning Electron Microscope (SEM, VEGA II TESCAN-LMU, Czech Republic) on pollens of S. nigra and S. ebulus. The pollen samples were obtained mostly from freshly collected herbarium specimens. For LM studies, the samples were acetolyzed following Erdtman's technique (Erdtman 1952). The measurements were based on at least 30 pollen grains per population. These were made with the help of an Olympus light microscope by using an Olympus DP12 Digital (Japan) Camera. For SEM investigation, the pollen grains were transferred directly to double-sided tape affixed stubs and were sputter-coated with gold plates. Photomicrographs were taken with a VEGA II TESCAN-LMU Electron Microscope at an accelerating voltage of 15-22 kV at Research Institute of Razi (Tehran, Iran). The applied terminology follows Punt et al. (2007). The characters of pollen grains of the studied Sambucus species are summarized in Tab. 2. In order to detect significant differences in the studied characters among the various studied species, analysis of variance (ANOVA) was done. To determine the species relationships, we have used cluster analysis and principal component analysis (PCA, Ingrouille 1986). For multivariate analysis, the mean of the quantitative characters was calculated. Qualitative characters were coded as binary or multistate. Variables were standardized for multivariate statistical analysis. Average taxonomic distances and squared Euclidean distances were done as dissimilarity coefficients in the cluster analysis of pollen data. In order to determine the most variable characters among the studied species, factor analysis based on principal component analysis was performed. SPSS ver. 19 (Chicago) and PAST ver. 2.17 (Hammer et al. 2001) softwares were applied for statistical analysis.

Seeds of the two species of Sambucus were taken from herbarium specimens. The seeds of every species were examined under the stereomicroscope to ensure the normal size and development, mounted directly on aluminum stubs using double-sided adhesive. After having been coated with a thin layer (ca. $25 \mathrm{~nm}$ ) of gold they were analyzed using a VEGA II TESCAN-LMU Electron Microscope at 


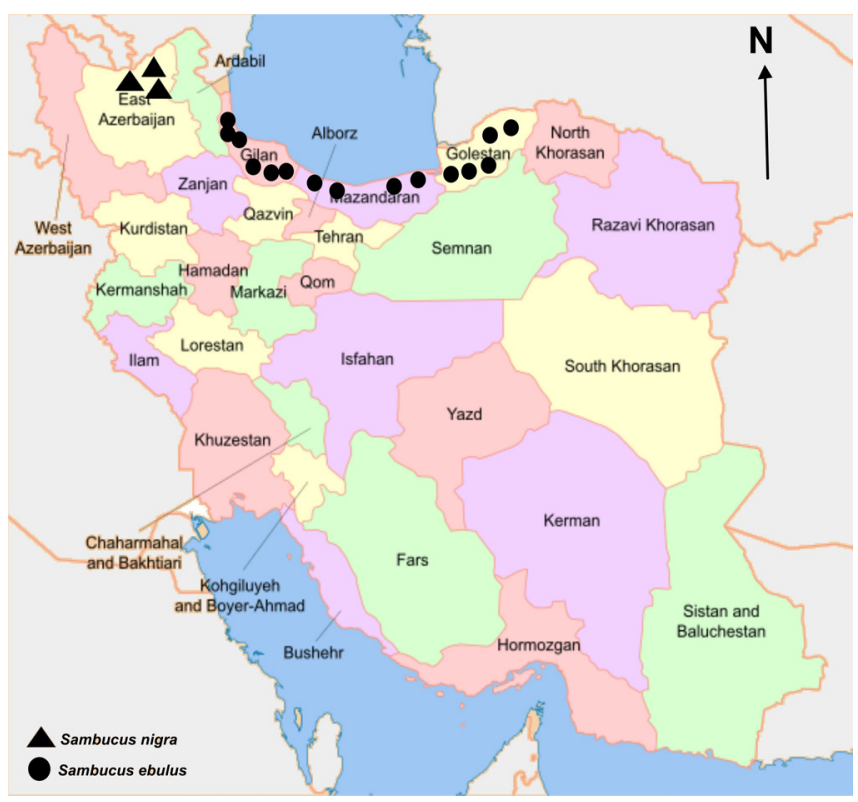

Fig. 1 Distribution map of studied species in Iran.

Tab. 1 List of species used in the study along with localities and vouchers.

\begin{tabular}{lcc}
\hline Taxon & DNA source (location, voucher) & $\begin{array}{c}\text { GenBank acces- } \\
\text { sion no. ITS }\end{array}$ \\
\hline S. nigra L. & East Azarbaijan: Arasbaran, Vayghan, Isazade-Araei, 803308, GKUH & LC466572 \\
S. nigra & East Azarbaijan: Arasbaran, Aynalu, Isazade-Araei, 803307, GKUH & LC466573 \\
S. nigra & East Azarbaijan: Arasbaran, Shabkhaneh, Isazade-Araei, 803309, GKUH & LC466574 \\
S. ebulus L. & Golestan: Gorgan, Tuskestan forest, Isazade-Araei, 803315, GKUH & LC466575 \\
S. ebulus & Golestan: Golestan National Park, Isazade-Araei, 803314, GKUH & LC466576 \\
S. ebulus & Golestan: Nowkandeh, Isazade-Araei, 803311, GKUH & LC466577 \\
S. ebulus & Golestan: Bandar Gaz, Isazade-Araei, 803310, GKUH & - \\
S. ebulus & Golestan: Kordkuy, Isazade-Araei, 803313, GKUH & - \\
S. ebulus & Mazandaran: Babol, Isazade-Araei, 803318, GKUH & LC466578 \\
S. ebulus & Mazandaran: Nur, Nurforest, Isazade-Araei, 803319, GKUH & LC466579 \\
S. ebulus & Mazandaran: Sari, Isazade-Araei, 803317, GKUH & - \\
S. ebulus & Mazandaran :6 km to Daryakenar, Isazade-Araei, 803326, GKUH & - \\
S. ebulus & Gilan: Lahijan, near to Rasht, Isazade-Araei, 803316, GKUH & LC466580 \\
S. ebulus & Gilan: Berenjanestak, Isazade-Araei, 803321, GKUH & LC466581 \\
S. ebulus & Gilan: Rasht, Isazade-Araei, 803322, GKUH & - \\
S. ebulus & Gilan: Lefur, Isazade-Araei, 803320, GKUH & - \\
S. ebulus & Gilan: Anzali, Isazade-Araei, 803323, GKUH & - \\
S. ebulus & Gilan: Lahijan, Isazade-Araei, 803324, GKUH & - \\
\hline
\end{tabular}




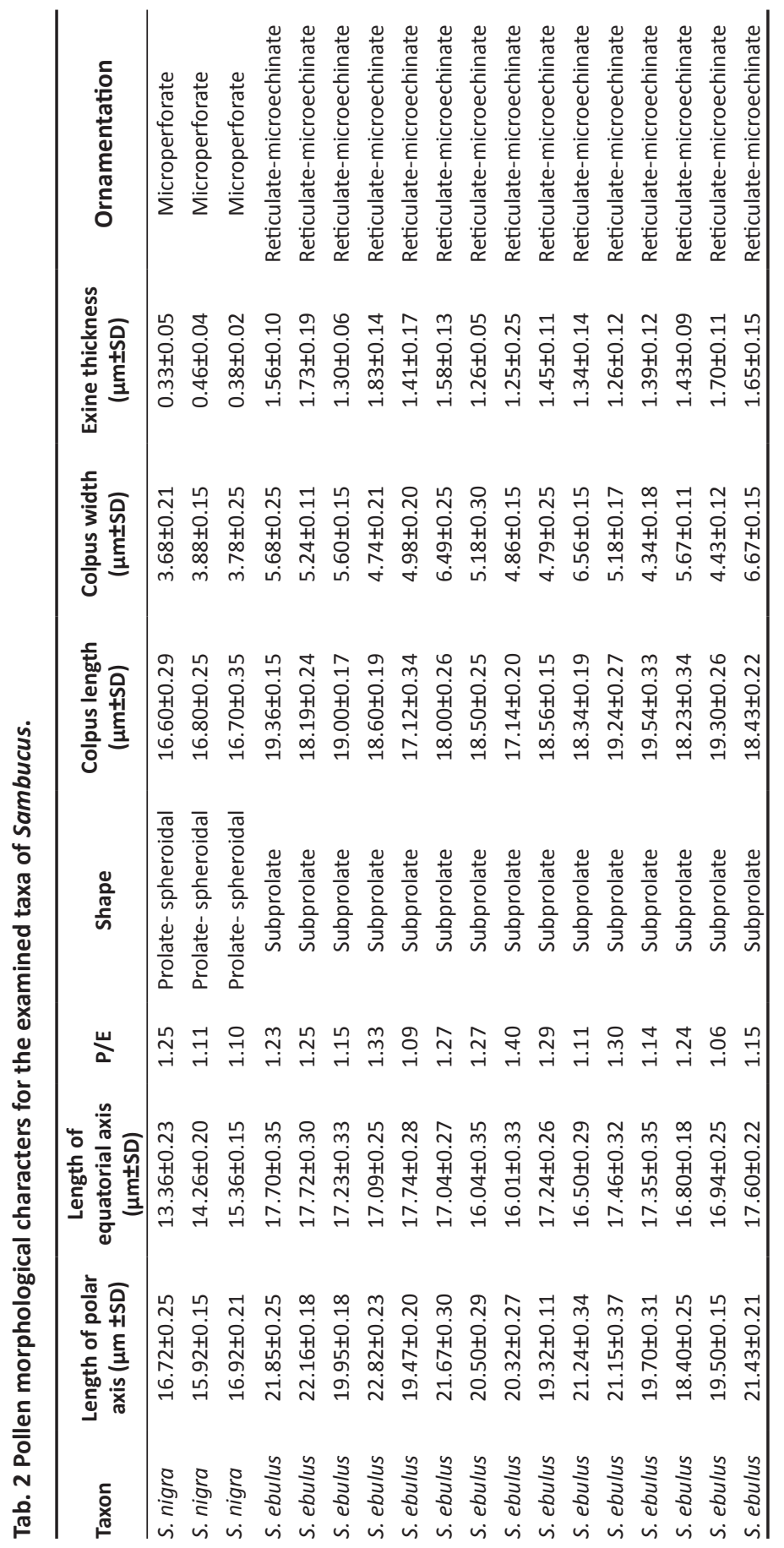


an accelerating voltage of 15-22 kV at Research Institute of Razi (Tehran, Iran). For recording gross morphology and size parameters, at least 10 seeds were measured. The list of voucher specimens and details of localities are given in Tab. 1.

\section{Anatomical methods}

The materials for anatomical studies were fixed in FAA (formalin-acetic acidalcohol) and preserved in $70 \%$ ethanol. Sections of petiole were taken manually, cleaned with sodium hypochlorite, stained with methyl green and carmen-vest. Sections were studied and photographed with the help of an Olympus light microscope by using a Olympus DP12 Digital Camera (Japan).

\section{Molecular methods}

\section{Taxon Sampling}

Sampling includes plants from three populations of $S$. nigra and seven populations of $S$. ebulus and were chosen as ingroup for nrDNA ITS. Viburnum opulus L. was chosen as outgroup following previous molecular phylogenetic studies (Errikson \& Donoghue 1997). A list of all the taxa used in this study and the sources, voucher information and GenBank accession numbers are given in Tab. 1.

\section{DNA extraction, PCR and sequencing}

Total genomic DNA was extracted from dried leaf materials deposited in Gonbad Kavous University herbarium (GKUH), using Kit method. The nrDNA ITS region was amplified using the primers ITS5m of Sang et al. (1995) and ITS4 of White et al. (1990). PCR amplification of the DNA regions followed procedures described in detail by Naderi Safar et al. (2014). The quality of PCR products was checked by electrophoresis in $1 \%$ agarose gels in $1 \times \mathrm{TAE}(\mathrm{pH}=8)$ buffer and were photographed with an UV gel documentation system (UVItec, Cambridge, UK). PCR products along with the same primers were sent for Sanger sequencing at Macrogen (Seoul, South Korea) through Pishgam Inc., Tehran-Iran.

\section{Sequence alignment}

Single dataset was aligned using the web-based version of MUSCLE (Edgar 2004, at http://www.ebi.ac.uk/Tools/msa/muscle/) under default parameters followed by manual adjustment. The alignment of dataset required the introduction of numerous single and multiple-base indels (insertions/deletions). Positions of indels were treated as missing data for the ITS dataset.

\section{Phylogenetic inferences}

\section{Maximum parsimony}

Maximum parsimony (MP) analyses were conducted using PAUP* version 4.0a157 (Swofford 2002). The heuristic search option was employed for nuclear dataset using tree bisection-reconnection (TBR) branch swapping, with 1000 
replications of random addition sequence and an automatic increase in the maximum number of trees. Uninformative characters were excluded from the analyses. Branch support values (MPBS) were estimated using a full heuristic search with 1000 bootstrap replicates (Felsenstein 1985) each with simple addition sequence.

\section{Bayesian inference}

For Bayesian inference (BI) analyses, models of sequence evolution were selected using the program MrModeltest version 2.3 (Nylander 2004) based on the Akaike information criterion (AIC) (Posada \& Buckley 2004). This program indicated a $\mathrm{GTR}+\mathrm{G}+\mathrm{I}$ model for nrDNA ITS, the best model for nucleotide substitution. $\mathrm{Bl}$ analyses were performed using MrBayes version 3.2 (Ronquist et al. 2012) on the CIPRES Science Gateway (Cyber infrastructure for Phylogenetic Research cluster) (Miller et al. 2010, https://www.phylo.org) for the dataset. Bayesian analyses were performed, with default priors (uniform priors) and the best-fit model of sequence evolution for dataset, with two runs of ten million generations and four simultaneous chains (one cold and three heated with a heating parameter of 0.2 ), by saving trees every 100 generations. The trees sampled after discarding $25 \%$ as "burn-in" were collected to build a $50 \%$ majority rule consensus phylogram and used to calculate posterior probability values (PP). Tree visualization was carried out using Tree View version 1.6.6 (Page 2001).

\section{Maximum likelihood}

Maximum likelihood (ML) analyses were carried out using the RAxML-HPC2 on XSEDE (8.2.8) at the CIPRES Science Gateway. Bootstrap values (LBS) were calculated in RAxML-HPC2 based on 1000 replicates with one search replicate per bootstrap replicate.

\section{Phylogenetic networks}

NeighborNet (NN) a distance-based network construction method (Bryant \& Moulton 2004) was implemented in SplitsTree4, version 4.14.4 (Huson \& Bryant 2006), based on the uncorrected $p$-distance between populations that was calculated from the ITS sequence data. The ITS matrice was modified prior to analysis by excluding the outgroup.

\section{Results}

\section{Pollen morphology}

The pollen grains of the studied species revealed some variations and separated two species of Sambucus. All palynological structures and measurements for the examined species concerning pollen type from polar view, polar $(P)$ and equatorial (E) measurements, $\mathrm{P} / \mathrm{E}$ ratio, pollen shape and exine ornamentation are shown in Tab. 2. Selected SEM micrographs of the pollens and their surfaces are shown in Fig. 2. Generally, type of pollen grain aperture is observed tricolporate among studied species (Fig. 2). Length of polar and equatorial axis were found useful 
in separating two species. Polar axis (P) length of pollen grains ranging from the smallest size for $S$. nigra $(15.92 \mu \mathrm{m})$ to the largest size for $S$. ebulus $(22.82 \mu \mathrm{m})$. Equatorial axis (E) length of pollen grains ranged from the smallest size in $S$. nigra $(13.36 \mu \mathrm{m})$ to the largest size in S. ebulus $(17.74 \mu \mathrm{m})$. The shape classes are based on the ratio between the length of polar axis $(P)$ and equatorial diameter(E). The $P / E$ ratio ranged from 1.09 to 1.33 , therefore the pollen shape is prolatespheroidal in $S$. nigra but subprolate in $S$. ebulus. Exine thickness in S. nigra $(0.33$ $\mu \mathrm{m})$ is smaller than $S$. ebulus $(1.83 \mu \mathrm{m})$. The exine sculpture is microperforate in S. nigra (Fig. 2B) and is reticulate-microechinate in S. ebulus (Fig. 2D).

In order to define the diagnostic value of pollen grains in species delimitations in studied Sambucus species, cluster analysis by Ward's method was performed on the base of eight qualitative and quantitative features (Fig. 3). Ward's dendrogram showed two main clusters (Fig. 3). First cluster composed of populations of $S$. nigra. Second cluster composed of two subclusters and contained populations of $S$. ebulus.

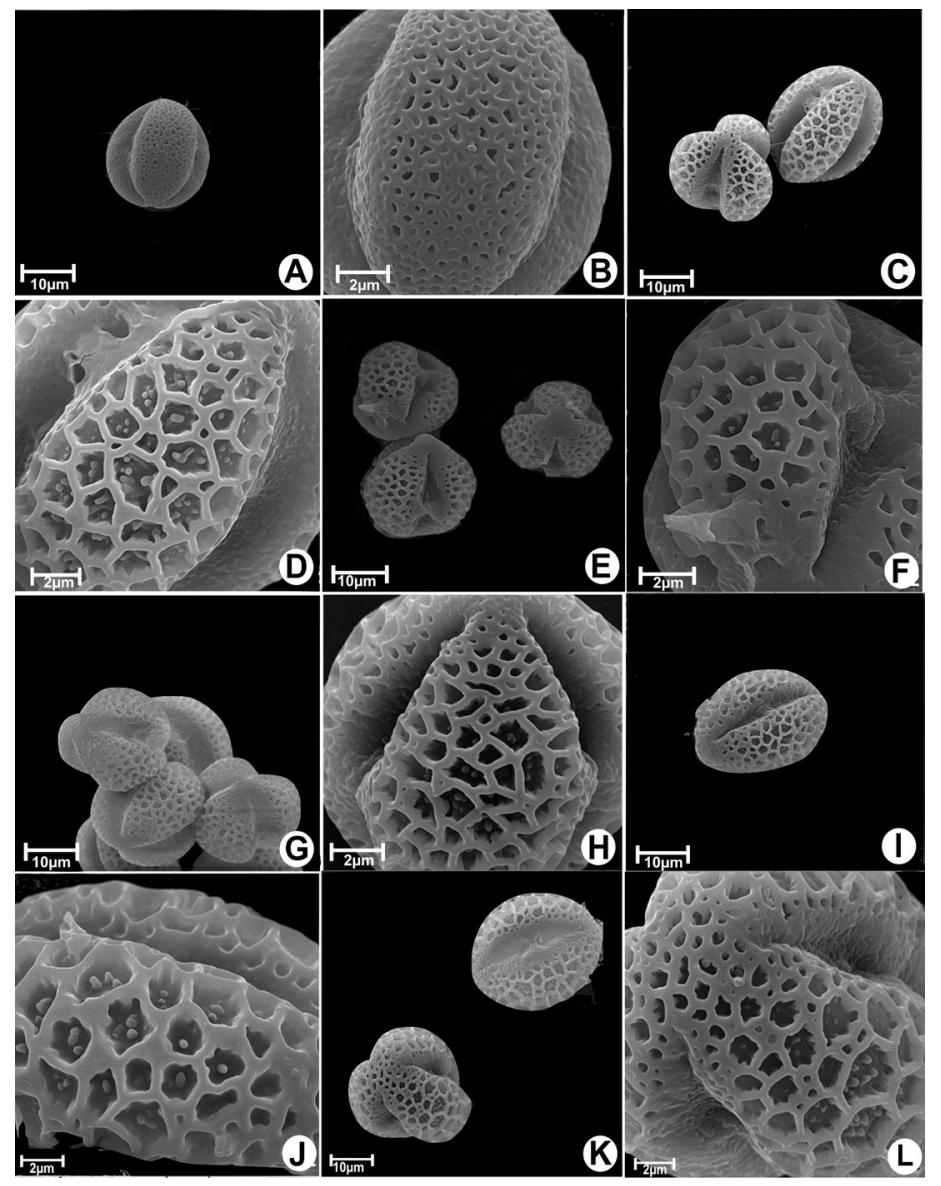

Fig. 2 Scanning electron micrographs (SEM) of pollen surface in $S$. nigra and $S$. ebulus. For each taxon the first micrograph shows the outline of the pollen indicating its general shape, and the second micrograph is a close view of the pollen surface. (A, B) S. nigra, (C, D) S. ebulus, (E, F) S. ebulus, (G, H) S. ebulus, $(\mathrm{I}, \mathrm{J}) \mathrm{S}$. ebulus, $(\mathrm{K}, \mathrm{L}) \mathrm{S}$. ebulus. 


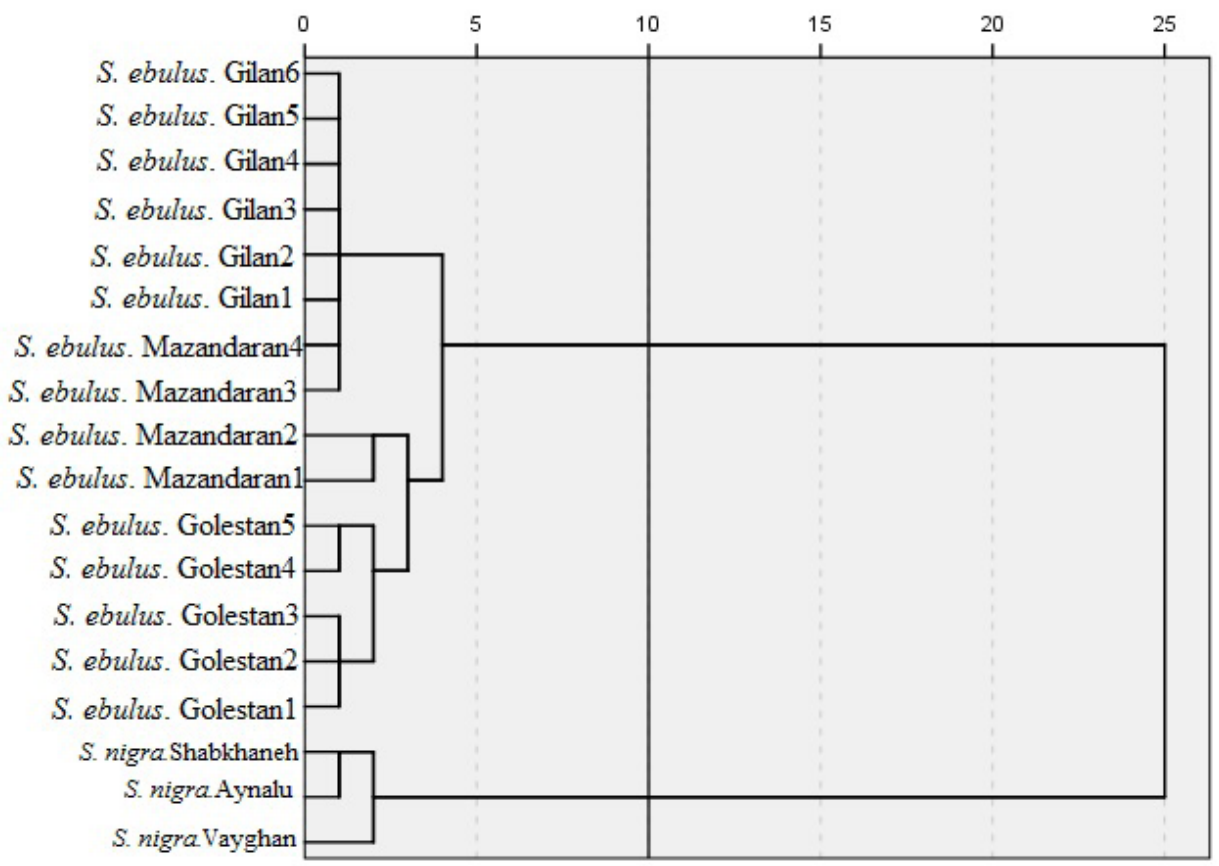

Fig. 3 Cluster analysis (Ward's method) based on pollen features of Sambucus.

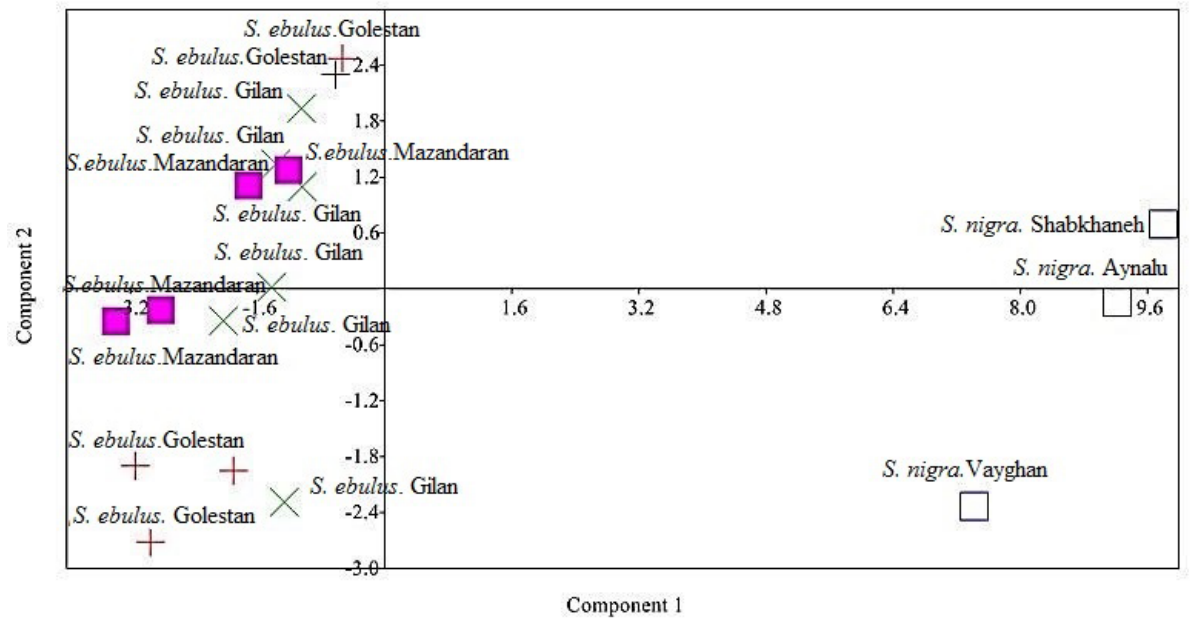

Fig. 4 PCA plot of Sambucus species based on observed pollen data. 
Principal component analysis revealed that there were two components providing more than $78 \%$ of total observed variation in studied pollen grains. Studying the component loadings it was evident that exine thickness and ornamentation of tectum are most important features in the first factor and pollen size, P/E ratio and shapes are most significant in the second factor. PCA confirmed the results of cluster analysis by Ward's method based on qualitative and quantitative features of pollen grains (Fig. 4).

\section{Seed shape and size}

Taxonomic importance of selected seed features in the examined taxa are summarized in Tab. 3. Selected SEM micrographs of the seeds and their surfaces are shown in Fig. 5. Seed size differs significantly between two species of Sambucus. Generally, seeds of $S$. ebulus are slightly smaller than those of $S$. nigra. The length of the seeds ranged from $2.62 \mathrm{~mm}$ in $S$. ebulus to $3.64 \mathrm{~mm}$ in S. nigra (column 2 in Tab. 3), and their width varied from $1.21 \mathrm{~mm}$ in S. ebulus to $1.42 \mathrm{~mm}$ in S. nigra (column 3 in Tab. 3). In general, the seeds are almond-shape.

\section{Seed Sculpturing}

In terms of exomorphology, the surface of the seed in S. nigra is smooth, not elongated and no clear organizational pattern is discernable and the anticlinal walls are shallowly undulate (Fig. 5B). In S. ebulus, the seeds have a microperforate surface and the anticlinal walls are observed deeply undulate (Fig. 5D, 5F \& 5H).

\section{Leaf anatomy}

Transverse sections from the leaf blades revealed the following elements (Fig. 6). The outline of the midrib in leaf blades are semicircular in both species. The epidermis is composed of single layered cells. The collenchyma tissue is located under the epidermis of the leaf blade. They are 4-5 layered in both species. The cortex tissue is composed of 4-5 layered parenchyma cells. Everywhere, but especially near the vascular bundle, cells with crystals of calcium oxalate can be frequently found in S. nigra (Fig. 6A). In S. nigra, the vascular tissue forms a single lamellary bundle, slightly curved toward the adaxial face, whereas there are 3-4 vascular bundles in S. ebulus. Both species showed a bifacial leaf anatomical structure, so the mesophyll is differentiated into palisade and spongy tissues. The spongy cells are almost elongated in S. ebulus.

\section{Phylogenetic analysis}

Detailed information about alignment characteristics, selected model of nucleotide substitution, as well as tree statistics from the single analysis of the nrDNA ITS region, are summarized in Tab. 4. The aligned nrDNA ITS matrix comprises 682 characters. The maximum parsimony, maximum likelihood and Bayesian analyses of the nrDNA ITS produced congruent trees and gave similar results. All members of this genus form a well-supported clade ( $P P=1, M L /$ BS=100/100) (Fig. 7). The Sambucus clade is composed of two clades. Clade I 


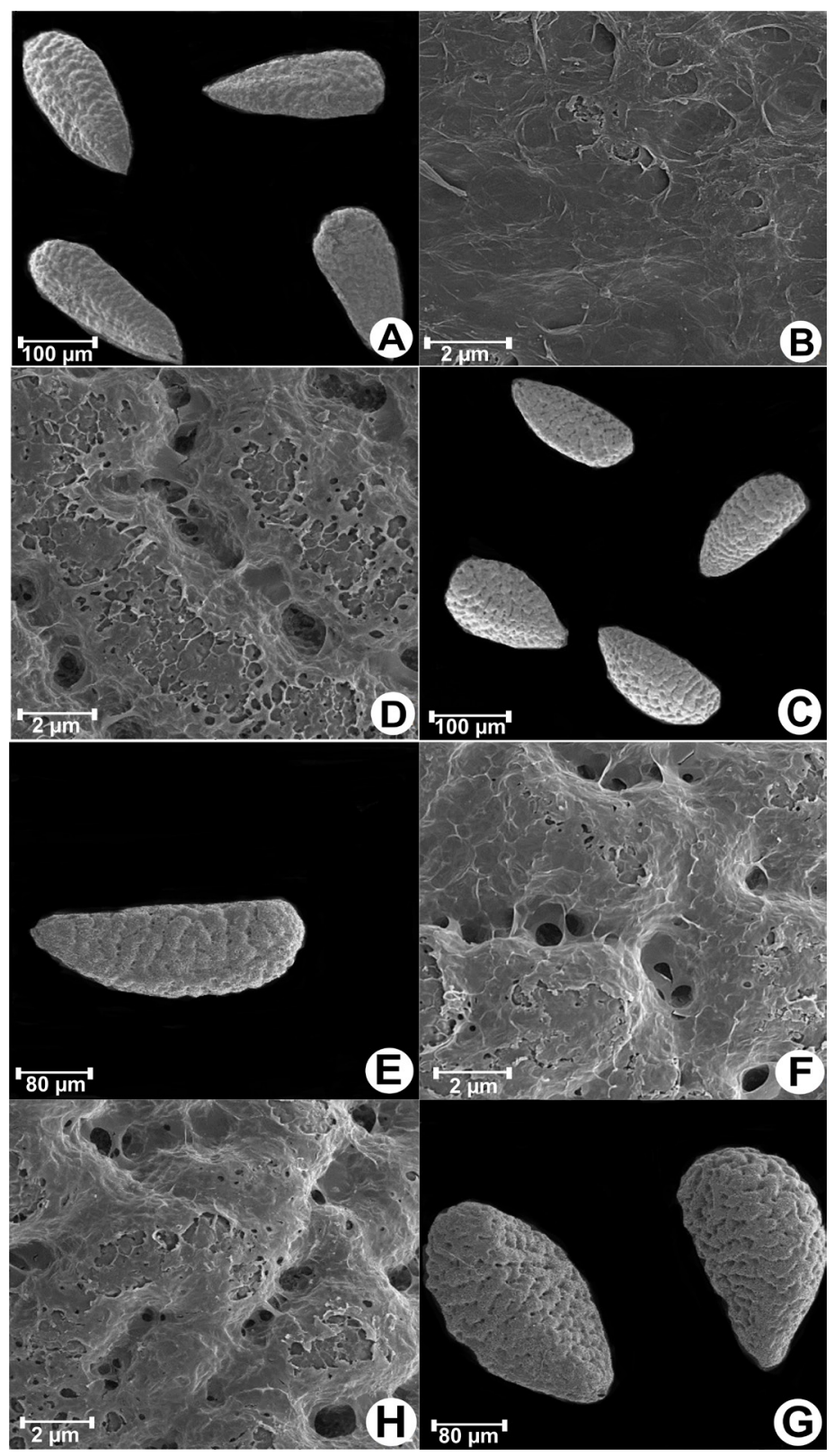

Fig. 5 Scanning electron micrographs (SEM) of seed surface in S. nigra and S. ebulus. For each taxon the first micrograph shows the outline of the seed indicating its general shape, and the second micrograph is a close view of the seed surface. (A, B) S. nigra, (C, D) S. ebulus, (E, F) S. ebulus, (G, H) S. ebulus. 


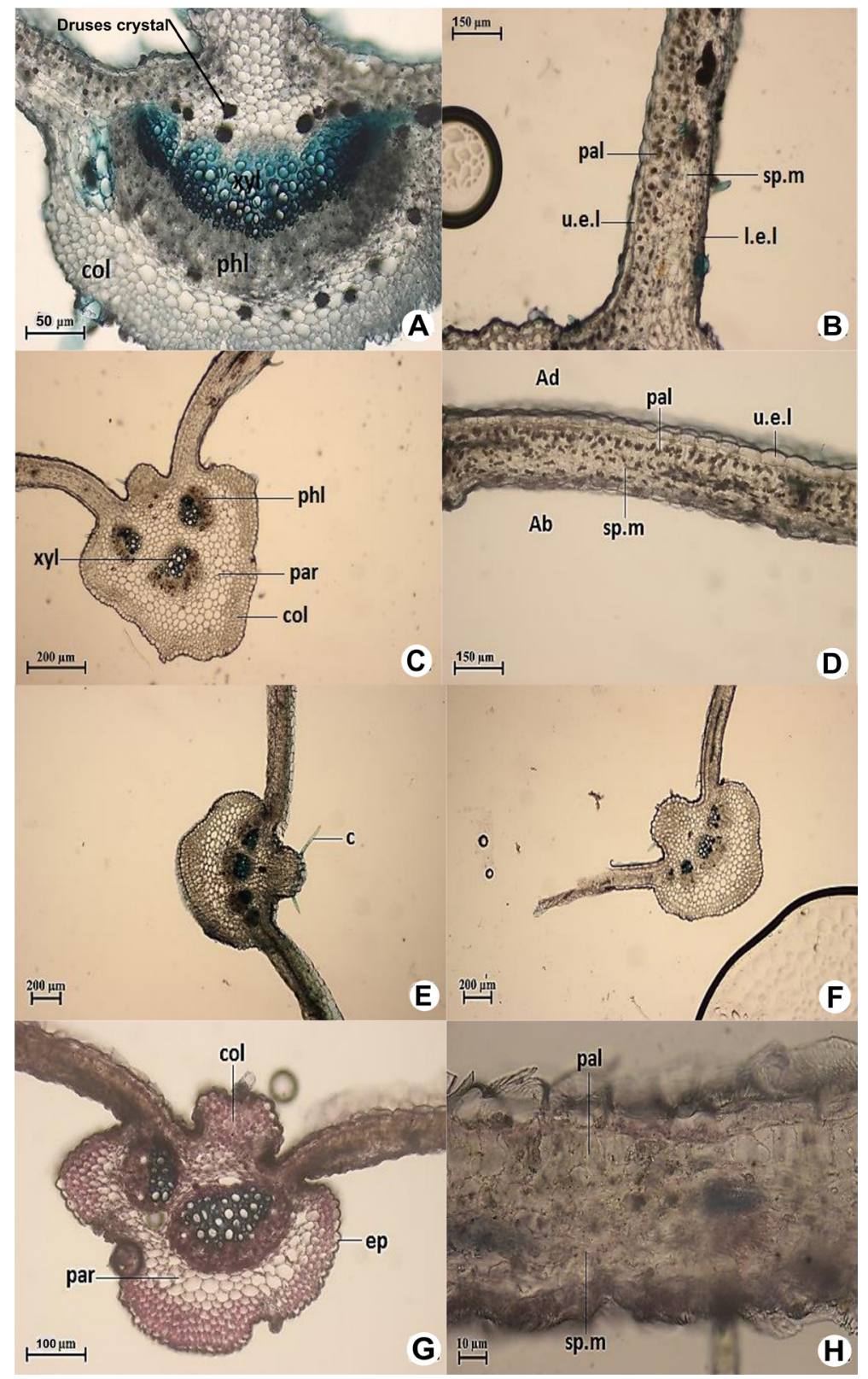

Fig. 6 (A, B) S. nigra, (C, D) S. ebulus, (E, F) S. ebulus, (G, H) S. ebulus. (Ad: Adaxial, Ab: Abaxial, u.e.I.: upper epiderm lamina, I.e.I.: lower epiderm lamina, I.e.m.: lower epiderm midrib, phl: phloem, xy: xylem, col: collenchymas, pal: palisade, sp.m.: spongy mesophyll, c: covering trichom). 


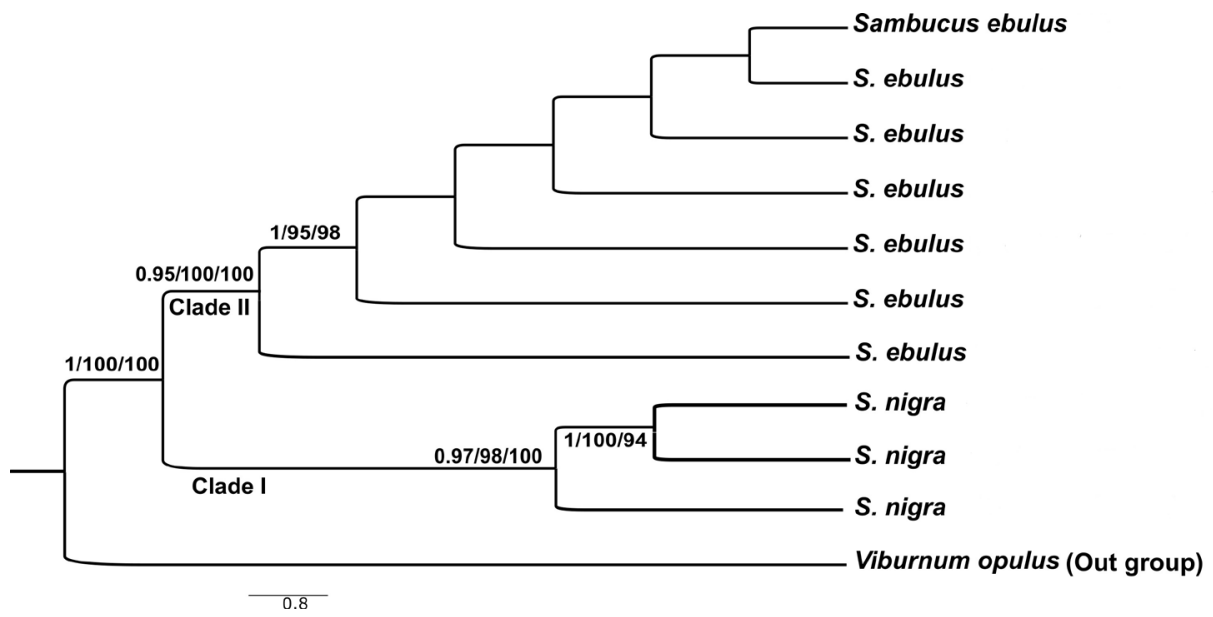

Fig. $750 \%$ majority rule consensus tree resulting from the Bayesian phylogenetic analysis of the nrDNA ITS dataset. Numbers of the branches are posterior probability (PP) from the BI and bootstrap support (BS) values from a MP and ML analysis, respectively (values $<50 \%$ were not shown).

Tab. 3 Some diagnostic seed micro-morphological features in species of Sambucus.

\begin{tabular}{lccccc}
\hline $\begin{array}{l}\text { Taxon (voucher } \\
\text { specimen) }\end{array}$ & $\begin{array}{c}\text { Length } \\
(\mathrm{mm} \pm \mathrm{SD})\end{array}$ & $\begin{array}{c}\text { Width } \\
(\mathrm{mm} \pm \mathrm{SD})\end{array}$ & Shape & Anticlinal wall & Sculpturing \\
\hline S. nigra (803308) & $3.64 \pm 0.15$ & $1.42 \pm 0.08$ & Almond & Shallowly undulate & Smooth \\
S. nigra (803307) & $3.53 \pm 0.18$ & $1.42 \pm 0.09$ & Almond & Shallowly undulate & Smooth \\
S. nigra (803309) & $3.43 \pm 0.13$ & $1.42 \pm 0.07$ & Almond & Shallowly undulate & Smooth \\
S. ebulus (803315) & $2.69 \pm 0.12$ & $1.25 \pm 0.20$ & Almond & Deeply undulate & Microperforate \\
S. ebulus (803314) & $2.63 \pm 0.12$ & $1.21 \pm 0.19$ & Almond & Deeply undulate & Microperforate \\
S. ebulus (803311) & $2.64 \pm 0.13$ & $1.23 \pm 0.10$ & Almond & Deeply undulate & Microperforate \\
S. ebulus (803318) & $0.14 \pm 2.67$ & $1.33 \pm 0.11$ & Almond & Deeply undulate & Microperforate \\
S. ebulus (803319) & $2.66 \pm 0.12$ & $1.31 \pm 0.13$ & Almond & Deeply undulate & Microperforate \\
S. ebulus (803316) & $2.67 \pm 0.15$ & $1.29 \pm 0.11$ & Almond & Deeply undulate & Microperforate \\
S. ebulus (803321) & $2.62 \pm 0.12$ & $1.27 \pm 0.12$ & Almond & Deeply undulate & Microperforate \\
\hline
\end{tabular}

includes the populations of $S$. nigra ( $P P=0.97, \mathrm{ML} / \mathrm{BS}=0.98 / 100)$ and the clade II (PP $=0.95, \mathrm{ML} / \mathrm{BS}=100 / 100)$ comprises the rest of the species of Sambucus (S. ebulus) (Fig. 7).

\section{Phylogenetic networks}

The NeighborNet diagram (Fig. 8) revealed almost complete separation of the studied populations within the network, supporting the phylogenetic results that the Sambucus is composed of two clades. Populations of S. nigra $(1,2 \& 3)$ are 
Tab. 4 Dataset and tree statistics from single analysis of the nuclear region.

\begin{tabular}{lc}
\hline Statistics / Characteristics & nrDNA ITS \\
\hline Number of sequences & 10 \\
Number of ingroup sequences & 9 \\
Alignment length [bp] & 682 \\
Number of parsimony-informative characters & 53 \\
Number of MPTs & 187 \\
Length of MPTs & 96 \\
Consistency index (CI) & 0.68 \\
Retention index (RI) & 0.81 \\
Evolutionary model selected (under AIC) & $\mathrm{GTR}+\mathrm{G}+\mathrm{I}$ \\
\hline
\end{tabular}

distinct and stand separately from the other populations at a major distance. The groups formed in the splits graph are readily correlated to the clades recovered in the phylogenies. We use the term "lineage" to refer to groups of specimens in the NN diagram (Fig. 8), and "clade" to refer to groups in the phylogenies (Fig. 7). The ITS splits graph revealed two main groups (Fig. 8). One of these, lineage "I" correlates to clade "I" in Fig. 7 and is composed of populations of S. nigra. The later, lineage "II" that is includes the populations of S. ebulus, corresponding to clade "II" in Fig. 7. Populations of $S$. ebulus $(4,5,6,7,8,9$ \& 10) show a more near genetic affinity and are placed close to each other.

\section{Lineage I}
1) Sambucus nigra
2) Sambucus nigra
3) Sambucus nigra
4) Sambucus ebulus
5) Sambucus ebulus
6) Sambucus ebulus
(7) Sambucus ebulus
(8) Sambucus ebulus
(9) Sambucus ebulus
i0) Sambucus ebulus
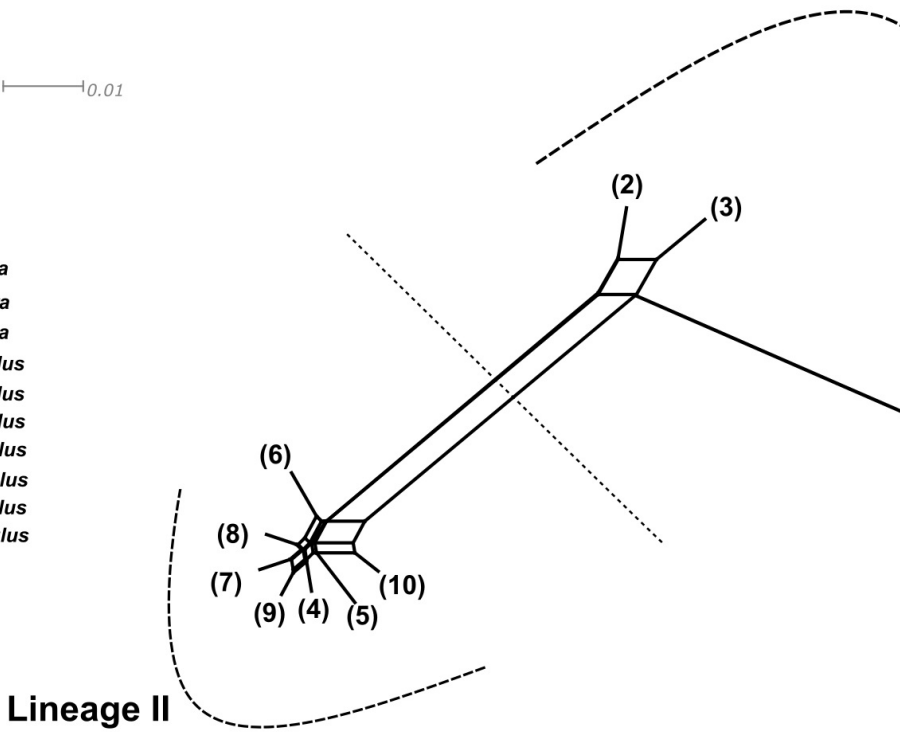

(2)

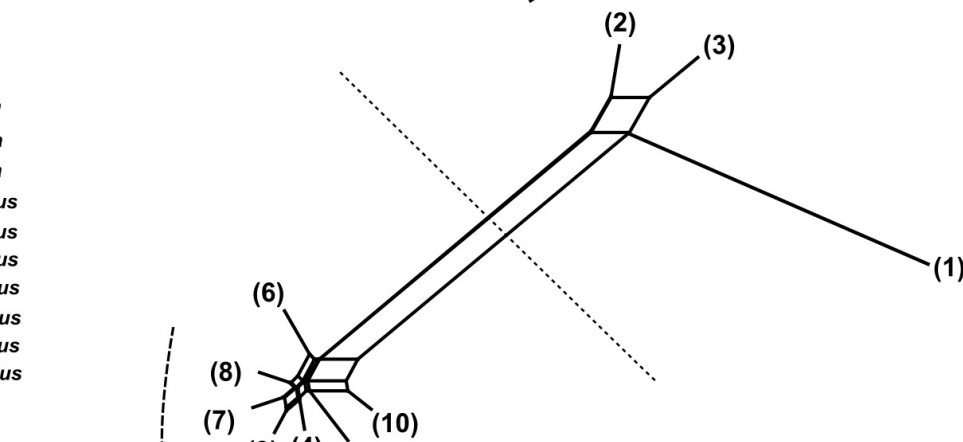

(9) (4) (5)

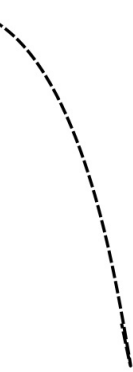

Fig. 8 NeighborNet for ITS sequences of Sambucus. Two major groups were recovered (i.e., lineage I and lineage II). 


\section{Discussion}

Sambucus has gained little attention in previous micro-morphological and phylogenetic studies, hence, this study presents the first comprehensive investigation of this genus in Iran. Micro-morphological evaluation of the Sambucus species has shown the diagnostic value of these characters. All pollen grains are small, tricolporate with prolate polar axis. Our results are consistent with the findings of Maciejewska (1997). Intraspecific pollen morphology of studied Sambucus species is homogeneous. Ornamentation of tectum in the area of apocolpia appears to be the most important quality feature for Sambucus pollen. Besides quantitative features (pollen size, $\mathrm{P} / \mathrm{E}$ ratio and thickness of exine) clearly separate $S$. ebulus from S. nigra. This finding confirms the result of Punt et al. (1976) that show two distinct pollen types of Sambucus. Our palynological investigations on different species of Sambucus confirmed importance of pollen traits for distinguishing taxa. As it is evident in PCA graph species are clearly separated by their pollen features.

All of the taxa have no difference in several aspects regarding seed shape, but the seed size and surface distinguished two species, so that $S$. nigra has no clear organizational pattern and anticlinal walls are seen shallowly wrinkle but S. ebulus has a microperforate surface and anticlinal walls are observed deeply undulate. Jacobs et al. (2010) revealed that the shape, size and surface characteristics of endocarps are variable in different Sambucus species, and are therefore useful for infrageneric classification and it is in concordance with our results. The present study emphasizes the findings of Hu et al. (1996) that transverse furrows and ridges on the surface are exclusively diagnostic of Sambucus endocarps.

The results of present study show that the number of vascular bundles and existence the crystals of calcium oxalate are diagnostic characters in studied species. Although, many features in two species are identical, there are some anatomical variations between S. nigra and S. ebulus. Our observations are in accordance with previous records in other Caprifoliaceae elements (Rugină \& Toma 2007; Gundersen 1910; Petit 1887).

Phylogenetic analyses displayed the monophyly of studied species with strong support and resolve relationships between two species. The issue of monophyly needs to be assessed critically in all molecular-based phylogenetic studies, especially when considering the weight currently being placed on phylogenies and the consequent implications for evolution, ecology, biogeography and more importantly taxonomic adjustments (Ramdhani et al. 2011). Nuclear molecular technique has been successfully used for investigation of infraspecific variations in different genera (Sheidai et al. 2014, 2016; Koohdar et al. 2016). Therefore, we decided to use the molecular approach for investigation of infraspecific variations between Sambucus species. Our results confirmed separation of these species. In the phylogram of nrDNA ITS and NeighborNet diagram, samples of each species were placed separately and we revealed complete separation of the studied populations. Separation of two species of Sambucus was recovered in nrDNA ITS phylogenetic study by Jacobs et al. (2009). In conclusion, the present work revealed the great difference between two species. These taxa differ in 
taxonomically important micro-morphological and molecular characteristics. Populations of S. ebulus nested in a polytomy, so it is necessary to use chloroplast markers and some other molecular techniques useful at the population level, for example AFLP, ISSR, microsatellites to better resolve the relationships between the populations of one species. A number of fast evolving genes will be necessary for resurrecting subspecies or verities in these two species.

\section{Acknowledgement}

The authors would like to thank Razi Institute (Tehran, Iran) staff for their assistance in scanning electron microscope, and all of persons who helped us in this research work.

\section{References}

Accorsi C. A., Bandini Mazzanti M., Forlani L. \& Speranza M. (1987): Morfologia pollinica di Sambucus L. in Italia. - Arch. Bot. Biogeogr. Ital. 63: 153-194.

Backlund A. \& Donoghue M. J. (1996): Morphology and phylogeny of the order Dipsacales. - In: Backlund A. (ed.): Phylogeny of the Dipsacales, p. 1-55. - Uppsala: Uppsala University.

Baldwin B. G., Sanderson M. J., Porter J. M., Wojciechowski M. F., Campbell C. S. \& Donoghue M. J. (1995): The ITS region of nuclear ribosomal DNA: a valuable source of evidence on angiosperm phylogeny. - Ann. Missouri Bot. Gard. 82/2: 247-277. DOI: $10.2307 / 2399880$

Bell C. D., Edwards E. J., Kim S. T. \& Donoghue M. J. (2001): Dipsacales phylogeny based on chloroplast DNA sequences. - Harvard Pap. Bot. 6/2: 481-499.

Bryant D. \& Moulton V. (2004): Neighbor-Net: An agglomerative method for the construction of phylogenetic networks. - Mol. Biol. Evol. 21/2: 255-265. https:// doi.org $/ 10.1093 / \mathrm{molbev} / \mathrm{msh} 018$

Chen K. G., Du F. G., Song J. H. \& Huang Y. (1992): A preliminary study on the pollen morphology of Sambucus in Jilin province. - J. Jilin Forest. Univ. 8: 39-46 (in Chinese, with English Abstract).

Donoghue M. J., Ericksson T., Reeves P. A. \& Olmstead R. G. (2001): Phylogeny and phylogenetic taxonomy of Dipsacales, with special reference to Sinadoxa and Tetradoxa (Adoxaceae). - Harvard Pap. Bot. 6/2: 459-479.

Donoghue M. J., Bell C. D. \& Winkworth R. C. (2003): The evolution of reproductive characters in Dipsacales. - Int. J. Plant Sci. 164/5: 453-464. DOI: 10.1086/376874

Du F. G., Zhu T. C., Zhu J. Y., Luan Z. H., Wang B. Q., Ma J. Y. \& Dong Y. (2007): Sculpture type of pollen surface of Sambucus Linn. in China. - J. Beihua Univ. Nat. Sci. 8: 271275 (in Chinese, with English Abstract).

Edgar R. C. (2004): Muscle: Multiple sequence alignment with high accuracy and high throughput. - Nucleic Acids Res. 32/5: 1792-1797. DOI: 10.1093/nar/gkh340

Erdtman G. (1952): Pollen Morphology and Plant Taxonomy. Angiosperms. Chronica Botanica Co., Waltham, Massachusettes. - Copenhagen.

Errikson T. \& Donoghue M. J. (1997): Phylogenetic relationships of Sambucus and Adoxa (Adoxoideae, Adoxaceae) based on nuclear ribosomal ITS sequences and preliminary morphological data. - Syst. Bot. 22/3: 555-573. DOI: 10.2307/2419828

Felsenstein J. (1985): Confidence limits on phylogenies: An approach using the bootstrap. - Evolution 39/4: 783-791. doi: 10.1111/j.1558-5646.1985.tb00420.x.

Gundersen A. L. (1910). - Recherches anatomique sur les Caprifoliaceae. Thèse. - Paris. 
Hammer O., Harper D. A. T \& Ryan P. D. (2001): PAST: Paleontological Statistics software package for education and data analysis. - Palaeonton. Electron. 4/1: 1-9.

Hu C. C. \& He C. X. (1988): Pollen morphology of Caprifoliaceae from China and its taxonomic significance. - J. Syst. Evol. 26/5: 343-352 (in Chinese, with English Abstract).

Hu R., Du F. G. \& Jiang B. W. (1996): A preliminary study on the seed morphology of Sambucus in Jilin province. - J. Jilin Forest. Univ. 12: 104-108 (in Chinese, with English Abstract).

Huson D. H. \& Bryant D. (2006): Application of phylogenetic networks in evolutionary studies. - Mol. Biol. Evol. 23/2: 254-267. DOI: 10.1093/molbev/msj030

Ingrouille M. J. (1986): The construction of cluster webs in numerical taxonomic investigation. - Taxon 35/3: 541-545. DOI: 10.2307/1221911

Jacobs B., Lens F. \& Smets E. (2009): Evolution of fruit and seed characters in the Diervilla and Lonicera clades (Caprifoliaceae, Dipsacales). - Ann. Bot. 104/2: 253-276. doi: 10.1093/aob/mcp131

Jacobs B., Huysmans S. \& Smets E. (2010): Evolution and systematic value of fruit and seed characters in Adoxaceae (Dipsacales). - Taxon 59/3: 850-866. DOI: $10.2307 / 25677673$

Jamzad Z. (1993): Sambucus L. - In: Assadi M., Khatamsaz M. \& Maassoumi A. A. (eds.): Flora of Iran 8. Dipsacaceae - Tehran: Research Institute of Forests and Rangelands.

Judd W. S., Sanders R. W. \& Donoghue M. J. (1994): Angiosperm Family Pairs: Preliminary Phylogenetic Analyses. - Harvard Pap. Bot. 1/5: 1-51.

Judd W. S., Campbell C. S., Kellogg E. A., Stevens P. F. \& Donoghue M. J. (2007): Plant systematics: a phylogenetic approach, 3rd edition. - Sunderland, M. A: Sinauer.

Koohdar F., Sheidai M., Talebi S. M., Noormohammadi Z. \& Ghasemzadeh-Baraki S. (2016): Genetic diversity, population structure and morphological variability in the Lallemantia royleana (Lamiaceae) from Iran. - Phytol. Balcan. 22/1: 29-38.

Mabberley D. J. (2008): The Plant Book, a Portable Dictionary of Higher Plants. Cambridge University Press. - Cambridge.

Maciejewska I. (1997): Pollen morphology of the polish species of the family Caprifoliaceae. Part 1. - Acta Soc. Bot. Poloniae 66/2: 133-142. DOI: 10.5586/ asbp.1997.017

Merica E., Lungu M., Balan I. \& Matei M. (2006): Study on the chemical composition of Sambucus nigra L. Essential oil and extracts. - Nutra Cos. 5/1: 25-27.

Miller M. A., Pfeiffer W. \& Schwartz T. (2010): Creating the CIPRES Science Gateway for Inference of Large Phylogenetic Trees. Proceedings of the Gateway Computing Environments Workshop (GCE), New Orleans, Louisiana. - Piscataway: IEEE. 45-52. DOI:10.1109/GCE.2010.5676129

Naderi Safar K., Kazempour-Osaloo Sh., Maassoumi A. A. \& Zarre Sh. (2014): Molecular phylogeny of Astragalus section Anthylloidei (Fabaceae) inferred from nrDNA ITS and plastid rp/32-trnL(UAG) sequence data. - Turkish J. Bot. 38/4: 637-652. DOI: 10.3906/bot-1308-44

Novelli S. (2003): Developments in berry production and use. - Bi-weekly Bul. 16: 5-6. Agriculture et Agroalimentaire Canada.

Nylander J. A. A. (2004): MrModeltest v2. Program distributed by the author. Evolutionary Biology Centre .- Uppsala University, Uppsala.

Page D. M. (2001): Tree View (Win32) version 1.6.6. Available: http:// taxonomy. zoology. gla.ac.uk/rod/treeview. html.

Petit L. (1887): - Le pétiole de Dicotylédones au point de vue de l'anatomie comparée et de la taxonomie. 
Posada D. \& Buckley T. R. (2004): Model selection and model averaging in phylogenetics: Advantages of akaike information criterion and Bayesian approaches over likelihood ratio tests. - Syst. Biol. 53/5: 793-808. DOI: 10.1080/10635150490522304

Punt W., Reitsma T. J. \& Reuvers, A. A. M. L. (1976): The Northwest European Pollen Flora, 2. Caprifoliaceae. - Rev. Palaeobot. Palynol. 17: 5-29.

Punt W., Hoen P. P., Blackmore S., Nilsson S. \& Thomas A. L. (2007): Glossary of pollen and spore terminology. - Rev. Palaeobot. Palynol. 143/1-2: 1-81. https://doi. org/10.1016/j.revpalbo.2006.06.008

Pyck N. \& Smets E. (2000): A search for the phylogenetic position of the seven-son flower (Heptacodium, Dipsacales): combining molecular and morphological evidence. Plant Syst. Evol. 225/1-4: 185-199. https://doi.org/10.1007/BF00985467

Pyck N., Roels P. \& Smets E. (1999): Tribal relationships in Caprifoliaceae: evidence from a cladistic analysis using $n d h F$ sequences. - Syst. Geogr. PI. 69/2: 185-199. DOI: $10.2307 / 3668539$

Ramdhani S., Barker N. P. \& Cowling R. M. (2011): Revisiting monophyly in Haworthia Duval (Asphodelaceae): Incongruence, hybridization and contemporary speciation. - Taxon 60/4: 1001-1014. DOI: 10.1002/tax.604005

Ronquist F., Teslenko M., Vandermark P., Ayres D. L, Darling A., Höhna S., Larget B., Liu L., Suchard M. A. \& Huelsenbeck J. P. (2012): MrBayes 3.2: efficient bayesian phylogenetic inference and model choice across a large model space. - Syst. Biol. 61/3: 539-542. DOI: 10.1093/sysbio/sys029

Rugină R. \& Toma C. (2007): Histo-anatomical aspects of some Lonicera L. species. Biologievegetală. 26-33.

Sang T., Crawford D. J. \& Stuessy T. (1995): Documentation of reticulate evolution in peonies (Paeonia) using internal transcribed spacer sequences of nuclear ribosomal DNA: Implication for biogeography and concerted evolution. - Proc. Natl. Acad. Sci. U. S. A. 92/15: 6813-6817. doi: 10.1073/pnas.92.15.6813

Sheidai M., Ziaee S., Farahani F., Talebi S. Y., Noormohammadi Z. \& HasheminejadAhangarani-Farahani Y. (2014): Infra-specific genetic and morphological diversity in Linum album (Linaceae). - Biologija 69/1: 32-39. DOI: 10.2478/s11756-013-0281-4

Sheidai M., Taban F., Talebi S. M. \& Noormohammadi Z. (2016): Genetic and morphological diversity in Stachys lavandulifolia (Lamiaceae) populations. - Biologija 62/1: 9-24. DOI:10.6001/biologija.v62i1.3286

Swofford D. L. (2002): PAUP*: Phylogenetic Analysis Using Parsimony (*and Other Methods), Version 4.0b10. - Sunderland: Sinauer Associates. DOI: 10.1111/j.00143820.2002.tb00191.x

Uncinimanganelli R. E., Zaccaro L. \& Tomei P. E. (2005): Antiviral activity in-vitro of Urtica dioica L., Parietaria diffusa and Sambucus nigra L. - J Ethnopharmacol. 98/3: 323327. DOI: 10.1016/j.jep.2005.01.021

Wendelbo P. (1965): Caprifoliaceae. - In: Rechinger K. H. (ed.): Flora Iranica 10. - Graz: Akademische Druck-u. Verlagsanstalt.

White T. J., Bruns T., Lee S. \& Taylor J. (1990): Amplification and direct sequencing of fungal ribosomal RNA genes for phylogenetics. - In: Innis D. H., Gelfand J. J., Sninsky et al. (eds.): PCR protocols: a guide to methods and applications, p. 315-322. Academic Press, San Diego. 